\title{
Biomass ashes and their phosphorus fertilizing effect on different crops
}

\author{
Katja Schiemenz $\cdot$ Bettina Eichler-Löbermann
}

Received: 1 November 2009/ Accepted: 8 February 2010/Published online: 12 March 2010

(C) The Author(s) 2010. This article is published with open access at Springerlink.com

\begin{abstract}
The reutilization of biomass ashes in agriculture is an important issue to create nutrient cycles and to save fertilizer. To analyse the $\mathrm{P}$ fertilization effect of crop biomass ashes (rape meal ash (RMA), straw ash (SA), and cereal ash (CA)) in interaction with different crops, two pot experiments with a poor loamy sand deficient in $\mathrm{P}$ were carried out. Besides the three ash treatments, other treatments included triple superphosphate (TSP) as a high soluble $\mathrm{P}$ source, potassium chloride $(\mathrm{KCl})$ as a high soluble $\mathrm{K}$ source, and a control (CON) without $\mathrm{P}$ and $\mathrm{K}$. The main crops (maize, lupin, summer barley, and oilseed rape) were cultivated in the first experiment from April to May and the catch crops (oil radish, phacelia, italian ryegrass, and buckwheat) were cultivated in the second experiment from August to September. Plant parameters (biomass and $\mathrm{P}$ uptake of shoots), soil $\mathrm{pH}$, different $\mathrm{P}$ pools of the soil (total $\mathrm{P}(\mathrm{Pt})$, water soluble $\mathrm{P}(\mathrm{Pw})$, double lactate soluble $\mathrm{P}(\mathrm{Pdl})$, oxalate soluble $\mathrm{P}$ (Pox)), P sorption capacity (PSC), and the degree of $P$ saturation (DPS) were investigated. The fertilization effect of biomass ashes was comparable with that of TSP. On average of all crops, the highest $\mathrm{P}$ uptake (86.7 mg pot ${ }^{-1}$ ) was found after RMA application, and the lowest $\mathrm{P}$ uptake $\left(66.6 \mathrm{mg} \mathrm{pot}^{-1}\right.$ ) for $\mathrm{CON}$. The
\end{abstract}

K. Schiemenz · B. Eichler-Löbermann $(\bowtie)$ Institute of Land Use, Faculty of Agriculture and Environmental Sciences, University of Rostock, Justus-von-Liebig-Weg 6, 18051 Rostock, Germany e-mail: bettina.eichler@uni-rostock.de readily bio-available soil $\mathrm{P}$ contents ( $\mathrm{Pw}$ and $\mathrm{Pdl}$ ) were significantly increased when $\mathrm{P}$ was supplied, regardless of whether $\mathrm{P}$ was given with ash or with high soluble TSP. The P fertilization effects also depended on the cultivated crops. The ash treatments resulted in highest increases of soil $\mathrm{Pw}$ values when combined with buckwheat cultivation. After buckwheat harvest the Pw content in the control was $8.0 \mathrm{mg} \mathrm{kg}^{-1}$, and in the ash treatments between $13.9 \mathrm{mg} \mathrm{kg}^{-1}$ (CA) and $15.7 \mathrm{mg} \mathrm{kg}^{-1}$ (RMA). From the results of this study we conclude, that crop biomass ashes can be an adequate $\mathrm{P}$ source comparable to that of highly soluble commercial P fertilizer.

Keywords Biomass ashes · Fertilization · P sorption · P uptake · Phosphorus ·

Soil P · Crops

\section{Introduction}

The largest amount of phosphorus (P) in the world is used for fertilizer, and the estimates of the duration of world-wide P-reserves are linked to the development of future agricultural needs and efficiency. The global $P$ resources, however, are limited and will probably be depleted within the next century (Haarr 2005). Therefore, solutions for $\mathrm{P}$ recycling by utilization of residues and wastes in agriculture become more important to save the world-wide $\mathrm{P}$ reserves. Ashes from combustion of biomass are the oldest mineral 
fertilizer in the world. In the context of increasing bioenergy production, the recycling of ashes in agriculture may solve the problem of ash disposal and reduce the necessity of commercial fertilizer application (Sander and Andrén 1997; Perucci et al. 2006).

Biomass ashes are nearly free of nitrogen but contain $\mathrm{P}$ and other nutrients needed for plant nutrition (Etiégni and Campbell 1991; Sander and Andrén 1997; Vance and Mitchell 2000; Zimmermann and Frey 2002; Patterson et al. 2004; Uckert 2004). Furthermore, biomass ashes can also be used as liming agents (Clapham and Zibilske 1992; Muse and Mitchell 1995; Mozaffari et al. 2002; Nkana et al. 2002; Odlare 2005; Mandre 2006). Ash application can stimulate the microbial activities and mineralization processes in the soil by amelioration of chemical and physical characteristics (Demeyer et al. 2001).

Nutrient composition and other properties of ashes are affected by different factors. Firstly, the kind of biomass combusted influences the quality and the nutrient values of ashes. Low available $P$ concentrations in ash of $0.01 \%$ were found in bagasse ash (Jamil et al. 2004). About 0.5\% P was found in municipal waste incinerator ash (Rosen et al. 1994) and cocoa husk ash (Onwuka et al. 2007). The $P$ content in alfalfa stem fly ash amounted to $0.9 \%$ (Mozaffari et al. 2002). For horticulture ashes, total $\mathrm{P}$ concentrations between 0.04 and $1.0 \%$ were described by Zhang et al. (2002). Patterson et al. (2004) found a total P concentration of $0.6 \%$ in wood waste ash (wood, bark, and knots). In investigations by Erich and Ohno (1992), Saarsalmi et al. (2001), and Hytönen (2003) wood ashes contained 0.9-1.7\% $\mathrm{P}$. In general, hardwood ash has more $\mathrm{P}$ than ash of softwood (Pitman 2006). P concentrations of more than $1 \%$ were detected in peat ash $(1.3 \%$, Hytönen 2003), in saw dust ash (1.3\%, Awodun 2007), and in different straw ashes: wheat straw ash $(1.3 \%)$, barley straw ash $(1.7 \%)$, rye straw ash $(1.6 \%)$, and rape straw ash (2.1\%) (Sander and Andrén 1997). For sewage sludge ashes, a total $\mathrm{P}$ concentration from 2 to 9\% can be assumed (Jakobsen and Willett 1986; Zhang et al. 2002; Franz 2008). Poultry litter ashes also contain high $\mathrm{P}$ contents of about $5.0 \%$ (Yusiharni 2001; Codling et al. 2002).

The liming effect is mainly connected with the $\mathrm{Ca}$ content and can also differ in dependence of the combustion material. Ash from rape straw had a higher $\mathrm{Ca}$ content and better liming effect than ash from cereal straw (Sander and Andrén 1997).

Beside the raw material used, the combustion process itself affects chemical composition of the ashes. In investigations of Eitégni and Campbell (1991) $\mathrm{P}$ concentration in wood ash varied between $1.7 \%$ (at $538^{\circ} \mathrm{C}$ ) and $2.6 \%$ (at $1093^{\circ} \mathrm{C}$ ) depending of combustion temperature. Furthermore, the utility of wood ash as a lime substitute also depended on boiler combustion efficiencies (Vance and Mitchell 2000).

The availability of nutrients in ashes can vary. According to Ohno and Erich (1990), only a small part of $\mathrm{P}$ added with wood ash appeared to be extractable and available for plants. A poor solubility of $\mathrm{P}$ in biomass ashes was also described by Pels et al. (2005). In contrast, positive effects of alfalfa stem ash on Olsen $\mathrm{P}$ in loamy soil (extracted with $\mathrm{NaHCO}_{3}$ ) were detected by Mozaffari et al. (2002). They found the relationship between ash application rate and extractable $\mathrm{P}$ content in soil could be described by a linear regression. Increased available $\mathrm{P}$ contents in soil and better growth of maize due to fertilization with cocoa husk ash were reported by Onwuka et al. (2007). Results of Van Reuler and Janssen (1996) showed significantly increased yields and $\mathrm{P}$ uptakes of upland rice fertilized with wood ash.

Other positive crop yield effects of ashes were also found for winter wheat (T. aestivum L.), spinach (S. oleracea L.), oat (A. sativa L.), and bean (P. vulgaris L.) (Clapham and Zibilske 1992; Krejsl and Scanlon 1996). Investigations of Patterson et al. (2004) showed an increase of 50\% for barley yield (H. vulgare L.) and up to $124 \%$ for oilseed yield of canola (B. rapa L.) due to wood ash application. In the tropics, Phongpan and Mosier (2003) found positive effects of rice hull ash on rice yield in Thailand, and Ikpe and Powell (2002) reported positive impacts of millet ash on millet yields.

Although these investigations showed a general potential of biomass ashes to increase crop growth and nutrient uptake, research concerning interactions of different kind of biomass ashes and various crops are rarely available. However, nutrient uptake efficiency and mobilization mechanisms of crops are important for high utilization of applied P (Schilling et al. 1998; Neumann 2007).

In our study we investigated three different crop biomass ashes and eight crop species within two experiments. In order to comprise a broad spectrum 
of ashes, based on different combustion materials, we selected straw ash, cereal ash and rape meal ash.

The objectives of this work were to

- compare the P fertilizing effect of different crop biomass ashes in comparison to a high soluble mineral P source, TSP,

- evaluate the ability of different main and catch crops to utilize $\mathrm{P}$ from biomass ashes for plant nutrition, and

- investigate possible interactions between the effects of fertilizing treatments and cultivated crops.

\section{Materials and methods}

\section{Soil}

In 2007 two pot experiments with a sandy soil (Table 1) were carried out in order to investigate the effect of biomass ashes on soil $\mathrm{P}$ pools and plant parameters. The soil used was taken from a long term field experiment located in Northern Germany (Rostock) which did not receive any $\mathrm{P}$ supply for 10 years. The double lactate soluble P content (Pdl) of about $39 \mathrm{mg} \mathrm{kg}^{-1}$ soil indicated a suboptimal $\mathrm{P}$ supply (Table 1). Contents of double lactate soluble $\mathrm{K}$ (about $115 \mathrm{mg} \mathrm{kg}^{-1}$ ) and $\mathrm{Mg}$ (about $120 \mathrm{mg} \mathrm{kg}^{-1}$ ) were optimal.

Treatments and experimental design

Different crop ashes derived from rape meal, straw and cereal were used to cover a broad spectrum of plant raw materials (Table 2). The rape meal ash (RMA) was produced at the University of Rostock, Faculty of Mechanical Engineering and Marine Technology (Germany) in a fluidized bed combustion at a temperature of $860^{\circ} \mathrm{C}$. The rye straw ash (SA) was produced via grate firing at $750^{\circ} \mathrm{C}$ and delivered by the Leibniz Institute for Agricultural Engineering in Potsdam-Bornim (Germany). The rye cereal ash (CA) was produced at the Agricultural Technical School of Tulln (Austria) also via grate firing at 650$850^{\circ} \mathrm{C}$. The biomass ashes varied in their nutrient composition (Table 2). The heavy metal contents of the biomass ashes are shown in Table 3 .

Mitcherlich pots were filled with $6 \mathrm{~kg}$ air-dried and sieved soil and irrigated with $600 \mathrm{ml}$ distilled water. The ashes/fertilizer were applied on the soil surface and mixed into the upper $5 \mathrm{~cm}$ of soil. For the

Table 1 Soil properties at the beginning of the pot experiments

\begin{tabular}{lllllll}
\hline Experiment & $\begin{array}{l}\mathrm{pH} \\
\mathrm{CaCl}_{2}\end{array}$ & $\begin{array}{l}\mathrm{Pw} \\
\left(\mathrm{mg} \mathrm{kg}^{-1}\right)\end{array}$ & $\begin{array}{l}\mathrm{Pdl} \\
\left(\mathrm{mg} \mathrm{kg}^{-1}\right)\end{array}$ & $\begin{array}{l}\mathrm{Pox} \\
\left(\mathrm{mmol} \mathrm{kg}^{-1}\right)\end{array}$ & $\begin{array}{l}\mathrm{DPS} \\
(\%)\end{array}$ & $\begin{array}{l}\mathrm{PSC} \\
\left(\mathrm{mmol} \mathrm{kg}^{-1}\right)\end{array}$ \\
\hline 1. Main crops & 5.65 & 10.7 & 38.9 & 11.96 & 38.92 & 30.77 \\
$\left(\mathrm{mg} \mathrm{kg}^{-1}\right)$
\end{tabular}

$P w$ water soluble $\mathrm{P}, P d l$ double lactate soluble $\mathrm{P}, P o x$ oxalate soluble $\mathrm{P}, D P S$ degree of $\mathrm{P}$ saturation, $P S C \mathrm{P}$ sorption capacity, $P t$ total $\mathrm{P}$; main crops maize, blue lupin, summer barley, oilseed rape; catch crops oil radish, phacelia, italian ryegrass, buckwheat

Table 2 Treatments of the pot experiments and the amount of nutrients given $\left(\mathrm{g} \mathrm{pot}^{-1} ; 6 \mathrm{~kg}\right.$ soil per pot)

\begin{tabular}{|c|c|c|c|c|c|c|c|c|c|}
\hline \multirow[t]{2}{*}{ Treatments } & \multirow[t]{2}{*}{ Abbr. } & \multicolumn{3}{|c|}{ Nutrient concentrations ${ }^{\mathrm{a}}(\%)$} & \multirow{2}{*}{$\begin{array}{l}\text { Fertilizer } \\
\text { application } \\
\text { rates }\left(\mathrm{g} \mathrm{pot}^{-1}\right)\end{array}$} & \multicolumn{4}{|c|}{$\begin{array}{l}\text { Nutrient amounts } \\
\left(\mathrm{g} \mathrm{pot}^{-1}\right)\end{array}$} \\
\hline & & $\mathrm{P}$ & $\mathrm{K}$ & $\mathrm{Mg}$ & & $\mathrm{N}$ & $\mathrm{P}$ & $\mathrm{K}$ & $\mathrm{Mg}$ \\
\hline Control & $\mathrm{CON}$ & - & - & - & - & 0.5 & - & - & - \\
\hline Phosphorus (TSP) & TSP & 20.2 & - & - & 1.0 & 0.5 & 0.2 & - & - \\
\hline Rape meal ash & RMA & 8.0 & 7.3 & 5.5 & 2.5 & 0.5 & 0.2 & 0.2 & 0.1 \\
\hline Straw ash & SA & 1.0 & 5.3 & 1.0 & 9.8 & 0.5 & 0.1 & 0.5 & 0.1 \\
\hline Cereal ash (from the seeds) & $\mathrm{CA}$ & 10.5 & 10.8 & 3.3 & 1.9 & 0.5 & 0.2 & 0.2 & 0.1 \\
\hline Potassium $(\mathrm{KCl})$ & $\mathrm{KCl}$ & - & 52.4 & - & 1.0 & 0.5 & - & 0.5 & - \\
\hline
\end{tabular}

a Total amount, aqua regia extraction 
Table 3 Heavy metal contents $\left(\mathrm{mg} \mathrm{kg}^{-1}\right)$ of the used biomass ashes

\begin{tabular}{lllllllr}
\hline Biomass ash & $\mathrm{Cd}$ & $\mathrm{Cr}$ & $\mathrm{Cu}$ & $\mathrm{Hg}$ & $\mathrm{Ni}$ & $\mathrm{Pb}$ & $\mathrm{Zn}$ \\
\hline RMA & 0.5 & 227.9 & 77.1 & 0.02 & 273.6 & 11.9 & 348.9 \\
SA & 0.1 & 4.7 & 24.5 & 0.02 & 3.7 & $<1.5$ & 80.9 \\
CA & 1.3 & 13.7 & 170.9 & 0.04 & 13.1 & 2.6 & 750.5 \\
\hline
\end{tabular}

RMA and CA treatment, $2.5 \mathrm{~g}$ ash and $1.9 \mathrm{~g}$ ash, respectively, were added per pot. These amounts corresponded to a nutrient supply of $0.2 \mathrm{~g} \mathrm{P}$ and $0.2 \mathrm{~g} \mathrm{~K}$ per pot. Due to the much lower $\mathrm{P}$ content in $\mathrm{SA}$, an application of $9.8 \mathrm{~g} \mathrm{SA}$ per pot contained only $0.1 \mathrm{~g}$ P but $0.5 \mathrm{~g} \mathrm{~K}$. Higher amounts of SA would have probably resulted in a too strong liming effect. To compare the $\mathrm{P}$ and $\mathrm{K}$ effect of ashes, treatments with high soluble TSP and $\mathrm{KCl}$ were also established (Table 2). Furthermore, a control (CON) without $\mathrm{P}$ and $\mathrm{K}$ supply was set up. Each pot received a nutrient solution with $1.4 \mathrm{~g} \mathrm{NH}_{4} \mathrm{NO}_{3}$ and $1.5 \mathrm{~g} \mathrm{MgSO}_{4}$ to supply $\mathrm{N}, \mathrm{Mg}$, and $\mathrm{S}$.

Depending on the favorable growing time of cultivated main crops and catch crops this study was split into two experiments. For both experiments the same soil and fertilization treatments were used. Only the cultivated crops differed (Table 4). The main crops (maize, blue lupin, summer barley, and oilseed rape) were seeded in April and the catch crops (oil radish, phacelia, italian ryegrass, and buckwheat) were seeded in August. After germination, the pots were placed outside in a cage under natural weather conditions. Distilled water was used for irrigation according to crop demands. Pots could drain freely to field capacity. Percolated water was collected in bowls below the pots and recirculated to avoid leaching losses. Plants grew until beginning of flowering and were harvested after a growing time of 46-66 days. Ryegrass was cut 3 times (after 31, 57 , and 88 days) within the growing period.

All treatments were replicated four times.

\section{Analyses}

Plant and soil samples were taken from each pot for analyses. Harvested shoots were dried in an oven at $60^{\circ} \mathrm{C}$, weighed and ground with a plant mill. The $\mathrm{P}$ content in plant tissue was measured after dry ashing using the vanadate-molybdate method (Page et al. 1982). Plant $P$ uptake was calculated by multiplying $\mathrm{P}$ content of the shoots and shoot biomass yield.

The soil samples were air-dried and sieved $(2 \mathrm{~mm})$ before analysis. Soil $\mathrm{pH}$ value was measured in $0.01 \mathrm{M} \mathrm{CaCl}_{2}$ using a 1:2.5 soil to solution ratio. For characterisation of soil $\mathrm{P}$ pools different methods were applied. The method described by Van der Paauw (1971) was used to determinate water-extractable P $(\mathrm{Pw})$ with a soil:water ratio of 1:25. The P concentrations in the extracts were measured by the phosphomolybdate blue method via flow-injection analysis. Content of double lactate soluble P (Pdl) (photometric method) was quantified according to Blume et al. (2000). By means of ammonium oxalate method (Schwertmann 1964) the extractable amount of $\mathrm{P}$ (Pox) allows the estimation of inorganic $\mathrm{P}$ being adsorbed on amorphous $\mathrm{Fe}$ and $\mathrm{Al}$ oxides in the soil. Pox and oxalate-soluble $\mathrm{Al}$ and $\mathrm{Fe}$ content in soil (Alox, Feox) were analysed by shaking $2 \mathrm{~g}$ of soil in acid oxalate solution $(100 \mathrm{ml})$ for $1 \mathrm{~h}$ in the dark.
Table 4 Cultivated crops in the pot experiments

\begin{tabular}{lll}
\hline Crop species & Variety & $\begin{array}{l}\text { Number of plants } \\
\text { per pot (time of harvest) }\end{array}$ \\
\hline 1. Main crops & \\
Maize (Zea mays L.) & Abakus & 8 \\
Blue lupin (Lupinus angustifolius L.) & Borlu & 8 \\
Summer barley (Hordeum vulgare L.) & Barke & 15 \\
Oilseed rape (Brassica napus L.) & Landmark & 10 \\
2. Catch crops & & \\
Oil radish (Raphanus sativus L.) & Rutina & 10 \\
Phacelia (Phacelia tanacetifolia Benth.) & Boratus & NA \\
Italian ryegrass (Lolium multiflorum Lam.) & Gordo & NA \\
Buckwheat (Fagopyrum esculentum Moench) & Lifago & 6 \\
\hline
\end{tabular}


Concentrations of $\mathrm{P}, \mathrm{Al}$, and $\mathrm{Fe}$ were determined by inductively coupled-plasma optical emission spectroscopy (ICP-OES, JY 238, Jobin-Yvon, France) at $214.914 \mathrm{~nm}(\mathrm{P}), 396.152 \mathrm{~nm}(\mathrm{Al})$, and $259.940 \mathrm{~nm}$ (Fe) wave length. Using these data, the P-sorption capacity $(\mathrm{PSC}[\mathrm{mmol} \mathrm{kg}-1]=($ Alox + Feox $) / 2$ and the degree of $\mathrm{P}$ saturation (DPS $[\%]=\mathrm{Pox} /$ PSC $\times 100$ ) could be calculated according to Lookman et al. (1995) and Schoumans (2000). Total P (Pt) was analysed after aqua regia dissolution in a microwave oven (Mars Xpress, CEM GmbH, Kamp-Lintfort, Germany) followed by ICP spectroscopy.

\section{Statistics}

Soil and plant data corresponding to four spatial replications were subjected to analysis of variance (General linear model, GLM). The results are reported as main effects and interactions. The means of soil and plant parameters were compared by the Duncan multiple range test. Significance was determined at $P<0.05$, and significantly different means were indicated by using different letters.

\section{Results and discussion}

Effect of biomass ashes and cultivated crops on $\mathrm{P}$ uptake and shoot biomass

In general, $\mathrm{P}$ uptake was affected positively by $\mathrm{P}$ supply, independently of whether $\mathrm{P}$ was given as TSP or with ashes (Tables 5 and 6).
In comparison to $\mathrm{CON}$ the average crop $\mathrm{P}$ uptake increased up to $32 \%$ by the RMA treatment which was comparable to the TSP treatment. The effects of SA and CA were smaller, however they increased the $\mathrm{P}$ uptake in comparison to the control by 15 and $19 \%$, respectively. The plant $\mathrm{P}$ uptake in the $\mathrm{KCl}$ treatment was comparable to the CON (absolute values shown in Table 6).

Especially, the $\mathrm{P}$ uptakes of maize, oilseed rape, phacelia, and italian ryegrass were increased when ash was applied, with increases up to $47 \%$ compared to CON. Since ashes consist of different nutrients the measured ash effect regarding $\mathrm{P}$ uptake was most probably also related to liming and/or effects of other nutrients.

The fertilizing effects of the ashes differed in dependence of the cultivated crops. P uptake from RMA into oilseed rape and ryegrass was very efficient with an increase of 39 and $47 \%$ compared to $\mathrm{CON}$, whereas no significant increase in comparison to the CON occurred for oil radish and buckwheat. For CA, P uptake into maize increased by $34 \%$ compared to $\mathrm{CON}$, whereas lupin and summer barley did not show any significant increase. The raise of $\mathrm{P}$ uptake from SA into phacelia was high (36\% compared to CON), but not existent for oil radish and negligible for lupin (absolute values in Table 6). The SA effect on the P uptake of phacelia was even comparable to the RMA effect, although the $\mathrm{P}$ content in SA was much lower.

The fertilization effect on crop yield was found to be lower than on crop P uptake. Although, on average, the P supply (TSP or ash) increased the yields of the

Table 5 Effect of fertilizer treatments, crop species and interactions of both factors on shoot biomass, plant $\mathrm{P}$ uptake, pH, soil $\mathrm{P}$ pools, and $\mathrm{P}$ sorption parameters (two-factor analysis of variance)

\begin{tabular}{|c|c|c|c|c|c|c|c|c|c|}
\hline Source of variation & Shoot biomass & P uptake & $\mathrm{pH}$ & $\mathrm{Pw}$ & Pdl & Pox & DPS & PSC & $\mathrm{Pt}$ \\
\hline & \multicolumn{9}{|c|}{ Experiment with main crops (maize, lupin, summer barley, and oilseed rape) } \\
\hline Fertilizer & $0.001 * * *$ & $0.000 * * *$ & $0.000 * * *$ & $0.000 * * *$ & $0.000 * * *$ & $0.000 * * *$ & $0.000 * * *$ & $0.004 * *$ & $0.000 * * *$ \\
\hline Crop species & $0.000 * * *$ & $0.000 * * *$ & $0.000 * * *$ & $0.000 * * *$ & $0.000 * * *$ & $0.006 * *$ & $0.001 * * *$ & $0.022 *$ & $0.000 * * *$ \\
\hline \multirow[t]{2}{*}{ Fertilizer $\times$ Crop species } & $0.024 *$ & $0.000 * * *$ & $0.288 \mathrm{~ns}$ & $0.048^{*}$ & $0.003 * *$ & $0.401 \mathrm{~ns}$ & $0.224 \mathrm{~ns}$ & $0.000 * * *$ & $0.064 \mathrm{~ns}$ \\
\hline & \multicolumn{9}{|c|}{ Experiment with catch crops (oil radish, phacelia, italian ryegrass, and buckwheat) } \\
\hline Fertilizer & $0.790 \mathrm{~ns}$ & $0.000 * * *$ & $0.000 * * *$ & $0.000 * * *$ & $0.000 * * *$ & $0.000 * * *$ & $0.000 * * *$ & $0.694 \mathrm{~ns}$ & $0.000 * * *$ \\
\hline Crop species & $0.000 * * *$ & $0.000 * * *$ & $0.000 * * *$ & $0.000 * * *$ & $0.000 * * *$ & $0.001 * * *$ & $0.004 * *$ & $0.000 * * *$ & $0.000 * * *$ \\
\hline Fertilizer $\times$ Crop species & $0.124 \mathrm{~ns}$ & $0.172 \mathrm{~ns}$ & $0.097 \mathrm{~ns}$ & $0.000 * * *$ & $0.004 * *$ & $0.016^{*}$ & $0.006 * *$ & $0.149 \mathrm{~ns}$ & $0.072 \mathrm{~ns}$ \\
\hline
\end{tabular}

$P w$ water soluble $\mathrm{P}, P d l$ double lactate soluble $\mathrm{P}, P o x$ oxalate soluble $\mathrm{P}, D P S$ degree of $\mathrm{P}$ saturation, $P S C \mathrm{P}$ sorption capacity, $P t$ total $\mathrm{P}$

$* P \leq 0.05 ; * * P \leq 0.01 ; * * * P \leq 0.001 ; \mathrm{ns}=$ not significant 
Table 6 Shoot biomass (dry matter, $\mathrm{g} \mathrm{pot}^{-1}$ ) and $\mathrm{P}$ uptake of the shoots $\left(\mathrm{mg} \mathrm{pot}^{-1}\right.$ ) as affected by fertilization and crops species

\begin{tabular}{|c|c|c|c|c|c|c|c|c|}
\hline \multirow[t]{4}{*}{ Fert. } & \multicolumn{4}{|c|}{ Main crops } & \multicolumn{4}{|c|}{ Catch crops } \\
\hline & Maize & Lupin & $\begin{array}{l}\text { Summer } \\
\text { barley }\end{array}$ & $\begin{array}{l}\text { Oilseed } \\
\text { rape }\end{array}$ & Oil radish & Phacelia & $\begin{array}{l}\text { Italian } \\
\text { ryegrass }\end{array}$ & $\begin{array}{l}\text { Buck- } \\
\text { wheat }\end{array}$ \\
\hline & \multicolumn{8}{|c|}{ Shoot biomass } \\
\hline & $0.040 *$ & $0.024 *$ & $0.225 \mathrm{~ns}$ & $0.066 \mathrm{~ns}$ & $0.146 \mathrm{~ns}$ & $0.271 \mathrm{~ns}$ & $0.016^{*}$ & $0.440 \mathrm{~ns}$ \\
\hline $\mathrm{CON}$ & $46.2 \mathrm{ab}^{\mathrm{D}}$ & $11.6 \mathrm{ab}^{\mathrm{A}}$ & $26.4^{\mathrm{C}}$ & $15.3^{\mathrm{B}}$ & $16.8^{\mathrm{B}}$ & $25.9^{\mathrm{C}}$ & $10.8 \mathrm{ab}^{\mathrm{A}}$ & $35.9^{\mathrm{D}}$ \\
\hline TSP & $49.5 \mathrm{~b}^{\mathrm{D}}$ & $13.4 \mathrm{~b}^{\mathrm{A}}$ & $28.1^{\mathrm{C}}$ & $16.7^{\mathrm{B}}$ & $16.2^{\mathrm{A}}$ & $25.5^{\mathrm{B}}$ & $12.4 \mathrm{bc}^{\mathrm{A}}$ & $30.6^{\mathrm{B}}$ \\
\hline RMA & $48.7 b^{D}$ & $13.4 \mathrm{~b}^{\mathrm{A}}$ & $27.8^{\mathrm{C}}$ & $17.3^{\mathrm{B}}$ & $16.1^{\mathrm{A}}$ & $29.2^{\mathrm{B}}$ & $13.2 \mathrm{c}^{\mathrm{A}}$ & $30.1^{\mathrm{B}}$ \\
\hline SA & $48.4 \mathrm{~b}^{\mathrm{D}}$ & $12.0 \mathrm{ab}^{\mathrm{A}}$ & $27.7^{\mathrm{C}}$ & $16.7^{\mathrm{B}}$ & $13.3^{\mathrm{A}}$ & $32.6^{\mathrm{B}}$ & $12.3 \mathrm{bc}^{\mathrm{A}}$ & $32.2^{\mathrm{B}}$ \\
\hline $\mathrm{CA}$ & $49.1 b^{D}$ & $11.1 \mathrm{a}^{\mathrm{A}}$ & $27.9^{\mathrm{C}}$ & $15.2^{\mathrm{B}}$ & $17.6^{\mathrm{B}}$ & $28.1^{\mathrm{C}}$ & $11.6 \mathrm{abc}^{\mathrm{A}}$ & $34.7^{\mathrm{D}}$ \\
\hline \multirow[t]{3}{*}{$\mathrm{KCl}$} & $42.2 \mathrm{a}^{\mathrm{D}}$ & $10.2 \mathrm{a}^{\mathrm{A}}$ & $28.7^{\mathrm{C}}$ & $15.4^{\mathrm{B}}$ & $16.5^{\mathrm{B}}$ & $27.9^{\mathrm{C}}$ & $10.0 \mathrm{a}^{\mathrm{A}}$ & $36.7^{\mathrm{D}}$ \\
\hline & \multicolumn{8}{|c|}{ P uptake of the shoots } \\
\hline & $0.000 * * *$ & $0.057 \mathrm{~ns}$ & $0.000 * * *$ & $0.000 * * *$ & $0.004 * *$ & $0.039 *$ & $0.000 * * *$ & $0.587 \mathrm{~ns}$ \\
\hline $\mathrm{CON}$ & $75.6 \mathrm{a}^{\mathrm{D}}$ & $25.3^{\mathrm{A}}$ & $59.1 \mathrm{a}^{\mathrm{C}}$ & $43.8 \mathrm{a}^{\mathrm{B}}$ & $64.2 \mathrm{abc}^{\mathrm{A}}$ & $99.8 \mathrm{a}^{\mathrm{B}}$ & $61.1 \mathrm{~b}^{\mathrm{A}}$ & $103.8^{\mathrm{B}}$ \\
\hline TSP & $109.2 \mathrm{~d}^{\mathrm{D}}$ & $32.5^{\mathrm{A}}$ & $79.3 \mathrm{~d}^{\mathrm{C}}$ & $62.4 \mathrm{~d}^{\mathrm{B}}$ & $77.5 \mathrm{c}^{\mathrm{A}}$ & $127.2 b^{C}$ & $86.1 \mathrm{e}^{\mathrm{AB}}$ & $116.2^{\mathrm{BC}}$ \\
\hline RMA & $99.9 \mathrm{bc}^{\mathrm{D}}$ & $35.8^{\mathrm{A}}$ & $75.1 \mathrm{~cd}^{\mathrm{C}}$ & $60.9 \mathrm{~cd}^{\mathrm{B}}$ & $75.0 \mathrm{bc}^{\mathrm{A}}$ & $136.1 \mathrm{~b}^{\mathrm{B}}$ & $89.5 \mathrm{e}^{\mathrm{A}}$ & $121.5^{\mathrm{B}}$ \\
\hline SA & $91.4 b^{D}$ & $27.2^{\mathrm{A}}$ & $70.1 \mathrm{bc}^{\mathrm{C}}$ & $55.2 \mathrm{bc}^{\mathrm{B}}$ & $54.6 \mathrm{a}^{\mathrm{A}}$ & $135.9 \mathrm{~b}^{\mathrm{C}}$ & $70.2 \mathrm{c}^{\mathrm{A}}$ & $111.0^{\mathrm{B}}$ \\
\hline $\mathrm{CA}$ & $101.0 \mathrm{~cd}^{\mathrm{D}}$ & $25.9^{\mathrm{A}}$ & $61.7 \mathrm{a}^{\mathrm{C}}$ & $49.3 \mathrm{ab}^{\mathrm{B}}$ & $77.0 \mathrm{c}^{\mathrm{A}}$ & $129.5 b^{B}$ & $78.6 \mathrm{~d}^{\mathrm{A}}$ & $127.7^{\mathrm{B}}$ \\
\hline $\mathrm{KCl}$ & $70.8 \mathrm{a}^{\mathrm{C}}$ & $27.5^{\mathrm{A}}$ & $66.1 \mathrm{ab}^{\mathrm{C}}$ & $43.5 \mathrm{a}^{\mathrm{B}}$ & $62.6 \mathrm{ab}^{\mathrm{A}}$ & $116.4 \mathrm{ab}^{\mathrm{B}}$ & $51.8 \mathrm{a}^{\mathrm{A}}$ & $113.1^{\mathrm{B}}$ \\
\hline
\end{tabular}

CON control, TSP TripleSuperP, RMA rape meal ash, $S A$ straw ash, $C A$ cereal ash, $K C l$ potassium chloride

$* P \leq 0.05$; ** $P \leq 0.01$; *** $P \leq 0.001$; ns = not significant; $P<0.05$ (Duncan); different small letters indicate significant differences between the fertilization treatments within a column; different capital letters indicate significant differences between main crops or catch crops within a line

crops, this effect was only found to be significant for the monocotyl crops maize and italian ryegrass (Table 6). Positive yield effects of maize after fertilization with wood ash of up to $100 \%$ increasing rates were also found by Erich and Ohno (1992). In experiments of Adu-Dapaah et al. (1994) maize shoot biomass increased when cocoa pod husk ash was applied. Nkana et al. (1998) described yield increases of ryegrass of $244 \%$ compared to control when fertilized with wood ash. And Yusiharni (2001) found yield increasing effects of ash (chicken litter ash) for ryegrass cultivated on acid lateric soil.

Buckwheat and oil radish did not show any positive yield effect after P fertilization (ash or TSP), and had comparably high yields even without $\mathrm{P}$ supply. This reflects a high $\mathrm{P}$ efficiency. Probably buckwheat could mobilize sufficient $\mathrm{P}$ from soil reserves (see also below). A special adaptation of buckwheat on $\mathrm{P}$ deficient soils has previously been shown by Amann and Amberger (1989) and Suzuki et al. (2009).
The diverse effects of fertilization on yield and $\mathrm{P}$ uptake in dependence of cultivated crops can be explained with crop specific adaptation and mobilization mechanisms. Generally, crop plants have various strategies to influence either the spatial or the chemical availability of $\mathrm{P}$ in soil. Some plants adapt to low-P soil by changing their root morphology to explore a large soil volume, other excrete P-solubilizing compounds like organic acids, organic and inorganic ions, sugars, vitamins, nucleosides, and enzymes (Staunton and Leprince 1996; Dakora and Phillips 2002; Nurruzzaman et al. 2006).

Green fertilizer catch crops may enhance the $\mathrm{P}$ nutrition of succeeding crops by increasing the $\mathrm{P}$ availability in soil. This can be by direct $\mathrm{P}$ mobilization during the plant growth and/or after it, when decomposed catch crop biomass releases P (EichlerLöbermann et al. 2007). High P uptake of catch crops provides a high potential for $\mathrm{P}$ supply of the succeeding crops. According to our results buckwheat and 
Table 7 Effect of fertilizer treatments on $\mathrm{pH}, \mathrm{Pt}, \mathrm{Pw}, \mathrm{Pdl}$, Pox, and $\mathrm{P}$ sorptions parameters on average of main crops and catch crops Fert. $\quad$ Experiment with main crops (maize, lupin, summer barley, and oilseed rape)

\begin{tabular}{|c|c|c|c|c|c|c|c|}
\hline & $\begin{array}{l}\mathrm{pH} \\
0.002 * *\end{array}$ & $\begin{array}{l}\mathrm{Pw} \\
0.000^{* * *} \\
\left(\mathrm{mg} \mathrm{kg}^{-1}\right)\end{array}$ & $\begin{array}{l}\text { Pdl } \\
0.000 * * * \\
\left(\mathrm{mg} \mathrm{kg}^{-1}\right)\end{array}$ & $\begin{array}{l}\text { Pox } \\
0.000 * * * \\
\left(\mathrm{mmol} \mathrm{kg}^{-1}\right)\end{array}$ & $\begin{array}{l}\text { DPS } \\
0.000 * * * \\
(\%)\end{array}$ & $\begin{array}{l}\text { PSC } \\
0.031 * \\
\left(\mathrm{mmol} \mathrm{kg}{ }^{-1}\right)\end{array}$ & $\begin{array}{l}\mathrm{Pt} \\
0.000 * * * \\
\left(\mathrm{mg} \mathrm{kg}^{-1}\right)\end{array}$ \\
\hline $\mathrm{CON}$ & $5.60 \mathrm{ab}$ & $8.4 \mathrm{a}$ & $33.7 \mathrm{a}$ & $12.3 \mathrm{a}$ & $40.8 \mathrm{a}$ & $30.1 \mathrm{c}$ & $503.8 \mathrm{a}$ \\
\hline TSP & $5.57 \mathrm{a}$ & $12.3 \mathrm{c}$ & $41.9 \mathrm{~b}$ & $13.4 \mathrm{~b}$ & $44.9 \mathrm{~b}$ & $29.9 \mathrm{bc}$ & $527.2 \mathrm{bc}$ \\
\hline RMA & $5.61 \mathrm{ab}$ & $11.5 \mathrm{bc}$ & $42.2 \mathrm{~b}$ & $13.1 \mathrm{~b}$ & $45.3 \mathrm{~b}$ & $29.0 \mathrm{a}$ & $532.2 \mathrm{c}$ \\
\hline SA & $5.72 \mathrm{c}$ & $11.2 \mathrm{bc}$ & $42.4 \mathrm{~b}$ & $12.4 \mathrm{a}$ & $42.6 \mathrm{a}$ & $29.2 \mathrm{ab}$ & $515.8 \mathrm{ab}$ \\
\hline $\mathrm{CA}$ & $5.68 \mathrm{bc}$ & $10.5 \mathrm{~b}$ & $42.2 \mathrm{~b}$ & $12.5 \mathrm{a}$ & $42.6 \mathrm{a}$ & $29.3 \mathrm{abc}$ & $516.3 \mathrm{ab}$ \\
\hline $\mathrm{KCl}$ & $5.58 \mathrm{a}$ & $8.2 \mathrm{a}$ & $33.5 \mathrm{a}$ & $12.3 \mathrm{a}$ & $41.2 \mathrm{a}$ & $29.8 \mathrm{abc}$ & $502.5 \mathrm{a}$ \\
\hline \multirow[t]{2}{*}{ Fert. } & \multicolumn{7}{|c|}{ Experiment with catch crops (oil radish, phacelia, italian ryegrass, and buckwheat) } \\
\hline & $\begin{array}{l}\mathrm{pH} \\
0.024 *\end{array}$ & $\begin{array}{l}\mathrm{Pw} \\
0.000^{* * *} \\
\left(\mathrm{mg} \mathrm{kg}^{-1}\right)\end{array}$ & $\begin{array}{l}\text { Pdl } \\
0.000 * * * \\
\left(\mathrm{mg} \mathrm{kg}^{-1}\right)\end{array}$ & $\begin{array}{l}\text { Pox } \\
0.000 * * * \\
\left(\mathrm{mmol} \mathrm{kg}^{-1}\right)\end{array}$ & $\begin{array}{l}\text { DPS } \\
0.000 * * * \\
(\%)\end{array}$ & $\begin{array}{l}\text { PSC } \\
\left.0.876 \mathrm{~ns}^{-1}\right) \\
\left(\mathrm{mmol} \mathrm{kg}^{-1}\right)\end{array}$ & $\begin{array}{l}\mathrm{Pt} \\
0.003^{* *} \\
\left(\mathrm{mg} \mathrm{kg}^{-1}\right)\end{array}$ \\
\hline $\mathrm{CON}$ & $5.31 \mathrm{a}$ & $8.6 \mathrm{a}$ & $30.3 \mathrm{a}$ & $11.9 \mathrm{a}$ & $40.1 \mathrm{a}$ & 29.8 & $516.3 \mathrm{ab}$ \\
\hline TSP & $5.30 \mathrm{a}$ & $13.0 \mathrm{~b}$ & $39.0 \mathrm{~b}$ & $12.6 \mathrm{bc}$ & $41.8 \mathrm{bc}$ & 30.1 & $533.7 \mathrm{c}$ \\
\hline RMA & $5.41 \mathrm{ab}$ & $12.5 \mathrm{~b}$ & $38.8 \mathrm{~b}$ & $12.8 \mathrm{~cd}$ & $42.5 \mathrm{c}$ & 30.2 & $534.5 \mathrm{c}$ \\
\hline SA & $5.52 \mathrm{~b}$ & $12.8 \mathrm{~b}$ & $41.6 \mathrm{~b}$ & $12.4 \mathrm{bc}$ & $41.9 \mathrm{bc}$ & 29.7 & $526.9 \mathrm{bc}$ \\
\hline $\mathrm{CA}$ & $5.34 \mathrm{ab}$ & $12.8 \mathrm{~b}$ & $39.7 \mathrm{~b}$ & $13.0 \mathrm{~d}$ & $43.3 \mathrm{c}$ & 30.2 & $530.7 \mathrm{bc}$ \\
\hline $\mathrm{KCl}$ & $5.22 \mathrm{a}$ & $8.2 \mathrm{a}$ & $31.6 \mathrm{a}$ & $12.2 \mathrm{ab}$ & $40.6 \mathrm{ab}$ & 30.0 & 509.8 a \\
\hline
\end{tabular}

$C O N$ control, $T S P$ TripleSuperP, $R M A$ rape meal ash, $S A$ straw ash, $C A$ cereal ash, $K C l$ potassium chloride, $P w$ water soluble $\mathrm{P}, P d l$ double lactate soluble P, Pox oxalate soluble P, DPS degree of P saturation, PSC P sorption capacity, Pt total P

$* P \leq 0.05$; ** $P \leq 0.01$; *** $P \leq 0.001$; ns $=$ not significant, different letters within a column indicate significant differences between the treatments; $P<0.05$ (Duncan)

phacelia, which had high $\mathrm{P}$ uptakes when fertilized with ashes, could be suitable to utilize P from ashes and to provide it to the following main crop.

Effect of biomass ashes and cultivated crops on soil characteristics

Generally, the fertilizer treatments as well as the crop species had a significant effect on $\mathrm{pH}$ value and soil $\mathrm{P}$ pools (Tables 5 and 7). For some parameters interactions could be found.

From the three applied ashes in the experiments, only SA caused significantly increased $\mathrm{pH}$ of the soil in comparison to the treatments without ash (Table 7), which is probably related to the high application rate of SA and the connected liming effect.

Among all crops, phacelia lead to the lowest $\mathrm{pH}$ values in the soil (Table 8). This was probably caused by a high cation:anion ratio of the nutrient uptake linked to an excretion of $\mathrm{H}_{3} \mathrm{O}^{+}$ions, as detected in former experiments (Eichler-Löbermann and Schnug 2006).

The bio-availability of $\mathrm{P}$ in the soil is not directly correlated to the absolute amount of $\mathrm{P}$, but depends on subsequent delivery from the soil $\mathrm{P}$ pools into soil solution. This delivery depends mainly on chemical soil characteristics like $\mathrm{pH}$. The better solubility of $\mathrm{Ca}$ phosphates under lower $\mathrm{pH}$ values can increase the effect of biomass ashes on more acid soils.

The P supply with ashes or with TSP resulted in a significant increase in readily plant available $\mathrm{P}$ forms Pw and Pdl (Table 7), whereas the effect of the crops was rather indifferent (Table 8). Remarkably, there were no differences in $\mathrm{Pw}$ contents of the soil between the $\mathrm{P}$ fertilizing treatments, even though commercial TSP fertilizer contain 80-93\% watersoluble P (Mullins and Sikora 1995) and the water solubility of $\mathrm{P}$ in crop ashes is usually lower than $1 \%$ (Eichler-Löbermann et al. 2008). Also concerning $\mathrm{Pdl}$, the same increasing effects of ashes and TSP 
Table 8 Chemical properties of soil ( $\mathrm{pH}, \mathrm{Pw}$, and $\mathrm{Pdl})$ in dependence of crop species and type of fertilization

\begin{tabular}{|c|c|c|c|c|c|c|c|c|}
\hline \multirow[t]{4}{*}{ Fert. } & \multicolumn{4}{|c|}{ Main crops } & \multicolumn{4}{|c|}{ Catch crops } \\
\hline & Maize & Lupin & $\begin{array}{l}\text { Summer } \\
\text { barley }\end{array}$ & $\begin{array}{l}\text { Oilseed } \\
\text { rape }\end{array}$ & Oil radish & Phacelia & $\begin{array}{l}\text { Italian } \\
\text { ryegrass }\end{array}$ & $\begin{array}{l}\text { Buck- } \\
\text { wheat }\end{array}$ \\
\hline & \multicolumn{8}{|l|}{$\mathrm{pH}$} \\
\hline & $0.005 * *$ & $0.036^{*}$ & $0.408 \mathrm{~ns}$ & $0.336 \mathrm{~ns}$ & $0.001 * * *$ & $0.240 \mathrm{~ns}$ & $0.002 * *$ & $0.006^{* *}$ \\
\hline $\mathrm{CON}$ & $5.49 \mathrm{ab}^{\mathrm{A}}$ & $5.54 \mathrm{ab}^{\mathrm{A}}$ & $5.67^{\mathrm{B}}$ & $5.71^{\mathrm{B}}$ & $5.36 \mathrm{~b}^{\mathrm{B}}$ & $5.04^{\mathrm{A}}$ & $5.57 \mathrm{a}^{\mathrm{C}}$ & $5.27 \mathrm{a}^{\mathrm{B}}$ \\
\hline TSP & $5.43 \mathrm{a}^{\mathrm{A}}$ & $5.51 \mathrm{a}^{\mathrm{AB}}$ & $5.69^{\mathrm{C}}$ & $5.65^{\mathrm{BC}}$ & $5.36 \mathrm{~b}^{\mathrm{B}}$ & $5.04^{\mathrm{A}}$ & $5.59 \mathrm{a}^{\mathrm{C}}$ & $5.19 \mathrm{a}^{\mathrm{B}}$ \\
\hline RMA & $5.54 \mathrm{ab}$ & $5.53 \mathrm{a}$ & 5.69 & 5.67 & $5.47 \mathrm{bc}^{\mathrm{B}}$ & $5.10^{\mathrm{A}}$ & $5.71 \mathrm{bc}^{\mathrm{C}}$ & $5.37 \mathrm{a}^{\mathrm{B}}$ \\
\hline SA & $5.70 \mathrm{c}$ & $5.67 \mathrm{~b}$ & 5.77 & 5.72 & $5.63 c^{B}$ & $5.06^{\mathrm{A}}$ & $5.80 \mathrm{c}^{\mathrm{C}}$ & $5.61 \mathrm{~b}^{\mathrm{B}}$ \\
\hline $\mathrm{CA}$ & $5.58 \mathrm{bc}^{\mathrm{A}}$ & $5.68 \mathrm{~b}^{\mathrm{AB}}$ & $5.69^{\mathrm{AB}}$ & $5.77^{\mathrm{B}}$ & $5.43 \mathrm{~b}^{\mathrm{B}}$ & $4.94^{\mathrm{A}}$ & $5.65 \mathrm{ab}^{\mathrm{C}}$ & $5.33 \mathrm{a}^{\mathrm{B}}$ \\
\hline \multirow[t]{3}{*}{$\mathrm{KCl}$} & $5.44 \mathrm{ab}^{\mathrm{A}}$ & $5.51 \mathrm{a}^{\mathrm{AB}}$ & $5.73^{\mathrm{C}}$ & $5.65^{\mathrm{BC}}$ & $5.15 \mathrm{a}^{\mathrm{AB}}$ & $4.94^{\mathrm{A}}$ & $5.57 \mathrm{a}^{\mathrm{C}}$ & $5.20 \mathrm{a}^{\mathrm{B}}$ \\
\hline & \multicolumn{8}{|c|}{$\mathrm{PW}\left(\mathrm{mg} \mathrm{kg}^{-1}\right)$} \\
\hline & $0.000 * * *$ & $0.018 *$ & $0.000 * * *$ & $0.000 * * *$ & $0.000 * * *$ & $0.000 * * *$ & $0.025^{*}$ & $0.000 * * *$ \\
\hline $\mathrm{CON}$ & $7.5 \mathrm{a}^{\mathrm{A}}$ & $10.4 \mathrm{ab}^{\mathrm{B}}$ & $7.8 \mathrm{a}^{\mathrm{A}}$ & $8.0 \mathrm{a}^{\mathrm{A}}$ & $8.7 \mathrm{a}^{\mathrm{AB}}$ & $8.1 \mathrm{a}^{\mathrm{A}}$ & $9.6 \mathrm{a}^{\mathrm{B}}$ & $8.0 \mathrm{a}^{\mathrm{A}}$ \\
\hline TSP & $10.7 \mathrm{bc}^{\mathrm{A}}$ & $15.3 c^{\mathrm{B}}$ & $11.5 \mathrm{c}^{\mathrm{A}}$ & $11.9 \mathrm{~b}^{\mathrm{A}}$ & $12.8 \mathrm{~b}$ & $11.3 \mathrm{~b}$ & $12.3 \mathrm{~b}$ & $15.5 \mathrm{~b}$ \\
\hline RMA & $10.8 \mathrm{bc}$ & $12.7 \mathrm{abc}$ & $10.0 \mathrm{~b}$ & $12.5 \mathrm{~b}$ & $12.5 \mathrm{~b}^{\mathrm{A}}$ & $11.0 \mathrm{~b}^{\mathrm{A}}$ & $10.9 \mathrm{ab}^{\mathrm{A}}$ & $15.7 b^{B}$ \\
\hline SA & $9.5 \mathrm{~b}^{\mathrm{A}}$ & $13.5 \mathrm{bc}^{\mathrm{B}}$ & $10.1 \mathrm{~b}^{\mathrm{A}}$ & $11.5 \mathrm{~b}^{\mathrm{AB}}$ & $15.5 \mathrm{c}^{\mathrm{B}}$ & $10.9 \mathrm{~b}^{\mathrm{A}}$ & $10.6 \mathrm{ab}^{\mathrm{A}}$ & $14.4 \mathrm{~b}^{\mathrm{B}}$ \\
\hline $\mathrm{CA}$ & $11.9 c^{\mathrm{B}}$ & $11.7 \mathrm{abc}^{\mathrm{B}}$ & $7.5 \mathrm{a}^{\mathrm{A}}$ & $11.1 \mathrm{~b}^{\mathrm{B}}$ & $12.7 \mathrm{~b}$ & $12.3 \mathrm{~b}$ & $12.2 \mathrm{~b}$ & $13.9 \mathrm{~b}$ \\
\hline \multirow[t]{3}{*}{$\mathrm{KCl}$} & $7.5 \mathrm{a}^{\mathrm{A}}$ & $9.2 \mathrm{a}^{\mathrm{C}}$ & $7.9 \mathrm{a}^{\mathrm{AB}}$ & $8.1 \mathrm{a}^{\mathrm{B}}$ & $8.4 \mathrm{a}^{\mathrm{B}}$ & $7.7 \mathrm{a}^{\mathrm{AB}}$ & $9.3 \mathrm{a}^{\mathrm{C}}$ & $7.6 \mathrm{a}^{\mathrm{A}}$ \\
\hline & \multicolumn{8}{|c|}{$\mathrm{Pdl}\left(\mathrm{mg} \mathrm{kg}^{-1}\right)$} \\
\hline & $0.000 * * *$ & $0.000 * * *$ & $0.000 * * *$ & $0.000 * * *$ & $0.000 * * *$ & $0.000 * * *$ & $0.000 * * *$ & $0.000 * * *$ \\
\hline $\mathrm{CON}$ & $33.0 \mathrm{a}$ & $34.7 \mathrm{a}$ & $33.3 \mathrm{a}$ & $33.8 \mathrm{a}$ & $31.7 \mathrm{a}^{\mathrm{C}}$ & $26.4 \mathrm{a}^{\mathrm{A}}$ & $33.7 \mathrm{a}^{\mathrm{D}}$ & $29.5 \mathrm{a}^{\mathrm{B}}$ \\
\hline TSP & $39.5 b^{A}$ & $44.9 \mathrm{~b}^{\mathrm{B}}$ & $41.9 \mathrm{~b}^{\mathrm{AB}}$ & $41.2 \mathrm{~b}^{\mathrm{A}}$ & $39.2 \mathrm{~b}^{\mathrm{B}}$ & $32.1 \mathrm{bc}^{\mathrm{A}}$ & $40.8 \mathrm{~b}^{\mathrm{BC}}$ & $43.8 \mathrm{~b}^{\mathrm{C}}$ \\
\hline RMA & $39.3 \mathrm{~b}$ & $44.7 \mathrm{~b}$ & $41.2 \mathrm{~b}$ & $43.5 \mathrm{~b}$ & $38.6 \mathrm{~b}^{\mathrm{B}}$ & $32.1 \mathrm{bc}^{\mathrm{A}}$ & $42.0 \mathrm{~b}^{\mathrm{B}}$ & $42.5 \mathrm{~b}^{\mathrm{B}}$ \\
\hline SA & $40.1 \mathrm{~b}$ & $45.8 \mathrm{~b}$ & $41.5 \mathrm{~b}$ & $42.0 \mathrm{~b}$ & $44.7 c^{B}$ & $34.4 \mathrm{~cd}^{\mathrm{A}}$ & $42.0 \mathrm{~b}^{\mathrm{B}}$ & $45.2 \mathrm{~b}^{\mathrm{B}}$ \\
\hline $\mathrm{CA}$ & $42.2 \mathrm{~b}^{\mathrm{B}}$ & $48.3 \mathrm{~b}^{\mathrm{B}}$ & $34.6 \mathrm{a}^{\mathrm{A}}$ & $43.5 b^{B}$ & $40.7 \mathrm{bc}^{\mathrm{B}}$ & $35.5 \mathrm{~d}^{\mathrm{A}}$ & $41.2 \mathrm{~b}^{\mathrm{B}}$ & $41.5 b^{B}$ \\
\hline $\mathrm{KCl}$ & $32.8 \mathrm{a}$ & $34.9 \mathrm{a}$ & $34.1 \mathrm{a}$ & $32.2 \mathrm{a}$ & $30.6 \mathrm{a}^{\mathrm{A}}$ & $30.4 \mathrm{~b}^{\mathrm{A}}$ & $34.2 \mathrm{a}^{\mathrm{B}}$ & $31.3 \mathrm{a}^{\mathrm{A}}$ \\
\hline
\end{tabular}

$C O N$ control, $T S P$ TripleSuperP, $R M A$ rape meal ash, $S A$ straw ash, $C A$ cereal ash, $K C l$ potassium chloride; $P w$ water soluble $\mathrm{P}, P d l$ double lactate soluble $\mathrm{P}$

$* P \leq 0.05$; ** $P \leq 0.01 ; * * * P \leq 0.001 ; \mathrm{ns}=$ not significant; $P<0.05$ (Duncan); different small letters indicate significant differences between the fertilization treatments within a column; different capital letters indicate significant differences between main crops or catch crops within a line

were found. A strong correlation was measured between $\mathrm{Pw}$ and $\mathrm{Pdl}$ in soil $(r=0.83 * * *)$.

Since the $\mathrm{P}$ cycle in soil is a very complex system and may be influenced by chemical, physical as well as by biological processes, changes in $\mathrm{Pw}$ and $\mathrm{Pdl}$ cannot only be explained by balancing the $\mathrm{P}$ input with fertilizer and the $\mathrm{P}$ output via crops harvest. However, oil radish and lupin which had rather low $\mathrm{P}$ uptakes (see above) resulted in relative high $\mathrm{Pw}$ and Pdl values after harvest, and phacelia which had the highest P uptake of all crops led to lower Pw and Pdl values. In contrast to this, the highest $\mathrm{Pw}$ values in the soil were found after buckwheat cultivation in the ash and TSP treatments (about $15.0 \mathrm{mg} \mathrm{kg}^{-1}$ soil), although buckwheat had high $\mathrm{P}$ uptakes. Also for Pdl, high values of about $43 \mathrm{mg} \mathrm{kg}^{-1}$ soil were found after buckwheat cultivation in the ash and TSP treatments (Table 8). These were comparable to those after oilseed rape cultivation, although the $\mathrm{P}$ uptake of buckwheat was double as high as for oilseed rape 
Table 9 Chemical properties of soil (Pox, DPS, PSC, and Pt) in dependence of crop species and type of fertilization

\begin{tabular}{|c|c|c|c|c|c|c|c|c|}
\hline \multirow[t]{4}{*}{ Fert. } & \multicolumn{4}{|c|}{ Main crops } & \multicolumn{4}{|c|}{ Catch crops } \\
\hline & Maize & Lupin & $\begin{array}{l}\text { Summer } \\
\text { barley }\end{array}$ & $\begin{array}{l}\text { Oilseed } \\
\text { rape }\end{array}$ & Oil radish & Phacelia & $\begin{array}{l}\text { Italian } \\
\text { ryegrass }\end{array}$ & $\begin{array}{l}\text { Buck- } \\
\text { wheat }\end{array}$ \\
\hline & \multicolumn{8}{|c|}{ Pox $\left(\mathrm{mmol} \mathrm{kg}{ }^{-1}\right)$} \\
\hline & $0.005^{* *}$ & $0.033 *$ & $0.360 \mathrm{~ns}$ & $0.016^{*}$ & $0.001 * * *$ & $0.022 *$ & $0.570 \mathrm{~ns}$ & $0.001 * * *$ \\
\hline $\mathrm{CON}$ & $12.5 \mathrm{ab}$ & $12.4 \mathrm{a}$ & 11.8 & $12.4 \mathrm{ab}$ & $11.8 \mathrm{a}$ & $12.0 \mathrm{a}$ & 11.7 & $12.2 \mathrm{a}$ \\
\hline TSP & $13.3 \mathrm{c}$ & $14.5 \mathrm{~b}$ & 12.7 & $13.3 \mathrm{c}$ & $12.3 \mathrm{ab}^{\mathrm{A}}$ & $12.8 \mathrm{~b}^{\mathrm{AB}}$ & $12.2^{\mathrm{A}}$ & $13.0 \mathrm{bc}^{\mathrm{B}}$ \\
\hline RMA & $13.5 \mathrm{c}$ & $13.1 \mathrm{a}$ & 12.8 & $13.2 \mathrm{bc}$ & $13.0 \mathrm{bc}^{\mathrm{B}}$ & $12.6 \mathrm{~b}^{\mathrm{AB}}$ & $12.1^{\mathrm{A}}$ & $13.4 c^{B}$ \\
\hline SA & $12.8 \mathrm{abc}$ & $12.3 \mathrm{a}$ & 12.3 & $12.3 \mathrm{a}$ & $12.4 \mathrm{ab}$ & $12.4 \mathrm{ab}$ & 12.3 & $12.5 \mathrm{ab}$ \\
\hline $\mathrm{CA}$ & $13.0 \mathrm{bc}^{\mathrm{B}}$ & $12.8 \mathrm{a}^{\mathrm{B}}$ & $11.9^{\mathrm{A}}$ & $12.2 \mathrm{a}^{\mathrm{AB}}$ & $13.9 c^{B}$ & $13.0 \mathrm{~b}^{\mathrm{AB}}$ & $12.3^{\mathrm{A}}$ & $13.0 \mathrm{bc}^{\mathrm{AE}}$ \\
\hline \multirow[t]{3}{*}{$\mathrm{KCl}$} & $12.2 \mathrm{a}$ & $12.5 \mathrm{a}$ & 12.3 & $12.1 \mathrm{a}$ & $12.2 \mathrm{ab}$ & $12.6 \mathrm{~b}$ & 12.1 & $11.9 \mathrm{a}$ \\
\hline & \multicolumn{8}{|l|}{ DPS (\%) } \\
\hline & $0.002 * *$ & $0.032 *$ & $0.071 \mathrm{~ns}$ & $0.002 * *$ & $0.005 * *$ & $0.002 * *$ & $0.439 \mathrm{~ns}$ & $0.018 *$ \\
\hline $\mathrm{CON}$ & $40.6 \mathrm{a}$ & $41.0 \mathrm{a}$ & 39.2 & $42.5 \mathrm{ab}$ & $39.7 \mathrm{a}^{\mathrm{AB}}$ & $38.0 \mathrm{a}^{\mathrm{A}}$ & $41.7^{\mathrm{B}}$ & $41.0 \mathrm{ab}^{\mathrm{B}}$ \\
\hline TSP & $44.7 \mathrm{c}$ & $47.7 \mathrm{~b}$ & 42.6 & $44.4 \mathrm{bc}$ & $42.7 \mathrm{a}$ & $41.1 \mathrm{~b}$ & 41.0 & $42.4 \mathrm{bc}$ \\
\hline RMA & $45.7 \mathrm{c}$ & $46.4 \mathrm{~b}$ & 43.4 & $45.7 \mathrm{c}$ & $42.6 \mathrm{a}$ & $40.9 \mathrm{~b}$ & 42.2 & $44.3 \mathrm{c}$ \\
\hline SA & $44.2 \mathrm{bc}^{\mathrm{B}}$ & $41.5 \mathrm{a}^{\mathrm{A}}$ & $42.8^{\mathrm{AB}}$ & $42.0 \mathrm{ab}^{\mathrm{A}}$ & $42.1 \mathrm{a}$ & $41.6 \mathrm{~b}$ & 43.4 & $40.5 \mathrm{ab}$ \\
\hline $\mathrm{CA}$ & $41.8 \mathrm{ab}$ & $43.7 \mathrm{ab}$ & 40.7 & $44.1 \mathrm{bc}$ & $46.2 \mathrm{~b}^{\mathrm{B}}$ & $42.3 \mathrm{~b}^{\mathrm{A}}$ & $42.6^{\mathrm{A}}$ & $42.0 \mathrm{bc}^{\mathrm{A}}$ \\
\hline \multirow[t]{3}{*}{$\mathrm{KCl}$} & $41.9 \mathrm{ab}$ & $43.2 \mathrm{ab}$ & 39.7 & $40.1 \mathrm{a}$ & $41.6 \mathrm{a}^{\mathrm{B}}$ & $40.3 \mathrm{~b}^{\mathrm{AB}}$ & $41.7^{\mathrm{B}}$ & $38.8 \mathrm{a}^{\mathrm{A}}$ \\
\hline & \multicolumn{8}{|c|}{ PSC $\left(\mathrm{mmol} \mathrm{kg}^{-1}\right)$} \\
\hline & $0.031 *$ & $0.033^{*}$ & $0.024 *$ & $0.018 *$ & $0.213 \mathrm{~ns}$ & $0.056 \mathrm{~ns}$ & $0.345 \mathrm{~ns}$ & $0.752 \mathrm{~ns}$ \\
\hline $\mathrm{CON}$ & $30.8 \mathrm{bc}$ & $30.2 \mathrm{~b}$ & $30.2 \mathrm{bc}$ & $29.1 \mathrm{~b}$ & $29.8^{\mathrm{AB}}$ & $31.6^{\mathrm{B}}$ & $28.1^{\mathrm{A}}$ & $29.9^{\mathrm{AB}}$ \\
\hline TSP & $29.7 \mathrm{abc}$ & $30.4 \mathrm{~b}$ & $29.8 \mathrm{abc}$ & $29.9 \mathrm{~b}$ & $28.7^{\mathrm{A}}$ & $31.2^{\mathrm{C}}$ & $29.8^{\mathrm{B}}$ & $30.6^{\mathrm{C}}$ \\
\hline RMA & $29.5 \mathrm{ab}^{\mathrm{B}}$ & $28.2 \mathrm{a}^{\mathrm{A}}$ & $29.5 \mathrm{ab}^{\mathrm{B}}$ & $28.8 \mathrm{ab}^{\mathrm{AB}}$ & $30.6^{\mathrm{B}}$ & $31.0^{\mathrm{B}}$ & $28.8^{\mathrm{A}}$ & $30.2^{\mathrm{AB}}$ \\
\hline SA & $29.1 \mathrm{a}$ & $29.7 \mathrm{~b}$ & $28.7 \mathrm{a}$ & $29.2 \mathrm{~b}$ & 29.3 & 29.9 & 28.4 & 31.0 \\
\hline $\mathrm{CA}$ & $31.1 \mathrm{c}^{\mathrm{C}}$ & $29.2 \mathrm{ab}^{\mathrm{B}}$ & $29.4 \mathrm{ab}^{\mathrm{B}}$ & $27.6 \mathrm{a}^{\mathrm{A}}$ & $30.0^{\mathrm{AB}}$ & $30.7^{\mathrm{B}}$ & $28.9^{\mathrm{A}}$ & $31.0^{\mathrm{B}}$ \\
\hline \multirow[t]{3}{*}{$\mathrm{KCl}$} & $29.1 \mathrm{a}$ & $29.0 \mathrm{ab}$ & $31.1 \mathrm{c}$ & $30.1 \mathrm{~b}$ & $29.4^{\mathrm{AB}}$ & $31.2^{\mathrm{C}}$ & $29.0^{\mathrm{A}}$ & $30.6^{\mathrm{BC}}$ \\
\hline & \multicolumn{8}{|c|}{$\mathrm{Pt}\left(\mathrm{mg} \mathrm{kg}^{-1}\right)$} \\
\hline & $0.037 *$ & $0.150 \mathrm{~ns}$ & $0.002 * *$ & $0.027 *$ & $0.000 * * *$ & $0.844 \mathrm{~ns}$ & $0.619 \mathrm{~ns}$ & $0.090 \mathrm{~ns}$ \\
\hline $\mathrm{CON}$ & $521 \mathrm{~b}^{\mathrm{B}}$ & $487^{\mathrm{A}}$ & $493 a b^{A}$ & $514 \mathrm{a}^{\mathrm{B}}$ & $529 \mathrm{~b}^{\mathrm{C}}$ & $511^{\mathrm{AB}}$ & $523^{\mathrm{BC}}$ & $502^{\mathrm{A}}$ \\
\hline TSP & $519 \mathrm{~b}$ & 526 & $523 \mathrm{c}$ & $541 \mathrm{ab}$ & $555 \mathrm{c}$ & 523 & 536 & 520 \\
\hline RMA & $526 \mathrm{~b}$ & 518 & $525 \mathrm{c}$ & $560 \mathrm{~b}$ & $548 \mathrm{bc}$ & 521 & 526 & 543 \\
\hline SA & $512 \mathrm{ab}$ & 509 & $513 \mathrm{bc}$ & 529 a & $545 \mathrm{bc}^{\mathrm{C}}$ & $522^{\mathrm{AB}}$ & $531^{\mathrm{BC}}$ & $509^{\mathrm{A}}$ \\
\hline CA & $534 b^{B C}$ & $507^{\mathrm{AB}}$ & $483 \mathrm{a}^{\mathrm{A}}$ & $541 \mathrm{ab}^{\mathrm{C}}$ & $553 c^{B}$ & $517^{\mathrm{A}}$ & $532^{\mathrm{AB}}$ & $519^{\mathrm{A}}$ \\
\hline $\mathrm{KCl}$ & $492 \mathrm{a}^{\mathrm{A}}$ & $505^{\mathrm{AB}}$ & $497 a b^{A}$ & $517 \mathrm{a}^{\mathrm{B}}$ & $504 \mathrm{a}^{\mathrm{A}}$ & $522^{\mathrm{B}}$ & $524^{\mathrm{B}}$ & $489^{\mathrm{A}}$ \\
\hline
\end{tabular}

CON control, TSP TripleSuperP, RMA rape meal ash, $S A$ straw ash, $C A$ cereal ash, $K C l$ potassium chloride, $P o x$ oxalate soluble $\mathrm{P}$, $D P S$ degree of $\mathrm{P}$ saturation, $P S C \mathrm{P}$ sorption capacity, $P t$ total $\mathrm{P}$

$* P \leq 0.05 ; * * P \leq 0.01 ; * * * P \leq 0.001 ;$ ns $=$ not significant; different small letters indicate significant differences between the fertilization treatments within a column; different capital letters indicate significant differences between main crops or catch crops within a line; $P<0.05$ (Duncan) 
(116 mg pot ${ }^{-1}$ and $53 \mathrm{mg}$ pot $^{-1}$, respectively). Probably buckwheat could mobilize $\mathrm{P}$ additionally to its own need. In investigations by Bekele et al. (1983), buckwheat has demonstrated high Ca-uptake rates followed by $\mathrm{H}^{+}$release which might be responsible for a shift in mass-action equilibrium favoring the solubility of poor soluble $\mathrm{P}$ sources. A very high $\mathrm{P}$ uptake efficiency from $\mathrm{Ca}$ phosphates was also reported for buckwheat by Zhu et al. (2002).

Specific effects of other crops on soil $\mathrm{P}$ contents became visible e.g. for the CA treatment. The combination of $\mathrm{CA}$ and barley resulted in very low $\mathrm{Pw}$ values of $7.5 \mathrm{mg} \mathrm{kg}^{-1}$ soil, which were comparable to the $\mathrm{CON}$, whereas a combination of CA and maize resulted in $\mathrm{Pw}$ values of $11.9 \mathrm{mg} \mathrm{kg}^{-1}$ soil, which tended to be the highest found for maize (Table 8).

For Pdl the cultivation of blue lupin in combination with CA resulted in about $40 \%$ higher values compared to $\mathrm{CON}$ (48.3 $\mathrm{mg} \mathrm{kg}^{-1}$ soil and $34.7 \mathrm{mg} \mathrm{kg}^{-1}$ soil, respectively), whereas the combination of summer barley and CA lead to very low Pdl content (34.6 mg $\mathrm{kg}^{-1}$ soil) (Table 8 ).

High Pdl values found for lupine are in accordance with the lower P uptake of lupine, and consequently lower exhaustion of $\mathrm{P}$ in soil. However, additional mobilizing effects could also have contributed to this high Pdl values. For lupin, a P mobilizing effect was found in many studies, albeit mainly for white lupin (L. albus) (Gilbert et al. 1999; Shen et al. 2003; Kania 2005) due to its cluster roots and an intense expression of root-induced chemical changes in the rhizosphere. According to results of Egle et al. (2003) and Pearse et al. (2007), blue lupin (L. angustifolius), which was used in our study, does not form root clusters, but does have a high solubilising effect related to efflux of carboxylates and excessive cation uptake.

The decrease of the readily available $\mathrm{P}$ contents directly after phacelia harvest is probably just a temporary process. In a long term field experiment with different catch crops used as green fertilizer, phacelia resulted in the highest increase of bio-available $P$ contents in soil (Eichler-Löbermann et al. 2007).

Application of $\mathrm{P}$ resulted in an increase of Pox contents in soil (Table 7), although this effect was lower than on $\mathrm{Pw}$ and Pdl. Increasing effects were mainly found for RMA and TSP. Differences in contents of Pox also depended on cultivated crops (Table 5). For the main crops after cultivation of lupin and maize the highest Pox contents were measured up to $14.5 \mathrm{mmol} \mathrm{kg}^{-1}$ (Table 9). For the catch crops, again buckwheat but also oil radish cultivation resulted in high Pox contents.

The DPS is related to what proportion the sorption sites in soil are occupied by Pox (Breeuwsma et al. 1995). Therefore, DPS values were closely related to Pox values and were affected by crop cultivation and fertilization (Table 5). The application of TSP or ashes generally caused the higher DPS values in comparison to the control (Table 7). The combination of lupin and TSP or RMA and oil radish combined with CA lead to the highest values of DPS (Table 9). By desorption processes, the sorbed $\mathrm{P}$ can be delivered into the soil solution and can contribute to plants $\mathrm{P}$ nutrition.

Fertilization effects on $\mathrm{Pt}$ were low in both experiments (Tables 7 and 9).

\section{Conclusions}

The utilization of biomass ashes as fertilizer can be an important strategy to create nutrient cycles in agriculture and to save nutrient resources. Based on our results, crop biomass ashes can be used as effective source for $\mathrm{P}$ fertilization on loamy sand. Generally, the ashes increased the crop P uptake as well as the readily plant available $\mathrm{P}$ pools in soil in comparison to the control.

The interactive effects of biomass ashes and cultivated crops may have an additional effect on $\mathrm{P}$ utilization from ashes. The crop effect on ash $\mathrm{P}$ utilization is probably related to specific adaptation and mobilization processes and needs further consideration. High $\mathrm{P}$ uptakes of green fertilizer catch crops can guarantee high $\mathrm{P}$ release after decomposition. Since catch crops additionally supply the soil with organic material, an application of crop biomass ashes to catch crops seems very promising. According to our results, a combination of ash fertilization with phacelia or buckwheat cultivation could be very positive in this sense.

Provided that ashes do not contain harmful concentrations of heavy metals or other toxic substances, biomass ashes can be applied in agriculture as a valuable fertilizer.

Acknowledgments This project is supported by the Federal Ministry of Food, Agriculture and Consumer Protection (BMELV), Germany (support code: 22016206). The project execution organization is the Agency for Renewable Resources (FNR), Germany. 
Open Access This article is distributed under the terms of the Creative Commons Attribution Noncommercial License which permits any noncommercial use, distribution, and reproduction in any medium, provided the original author(s) and source are credited.

\section{References}

Adu-Dapaah HK, Cobbina J, Asare EO (1994) Effect of cocoa pod ash on the growth of maize. J Agric Sci 122:31-33

Amann C, Amberger A (1989) Phosphorus efficiency of buckwheat (Fagopyrum esculentum). Z Pflanzenernähr Bodenk 152:181-189

Awodun MA (2007) Effect of sawdust ash on nutrient status, growth and yield of cowpea (Vigna unguiculata L. Walp). Asian J Agric Res 1(2):92-96

Bekele T, Cino BJ, Ehlert PAI et al (1983) An evaluation of plant-borne factors promoting the solubilization of alkaline rock phosphates. Plant Soil 75:361-378

Blume HP, Deller B, Leschber R et al (2000) Handbuch der Bodenuntersuchung. Terminologie, Verfahrensvorschriften und Datenblätter. Physikalische, chemische und biologische Untersuchungsverfahren. Gesetzliche Regelwerke. Wiley, Weinheim

Breeuwsma A, Reijerink JGA, Schoumans OF (1995) Impact of manure on accumulation and leaching of phosphate in areas of intensive livestock farming. In: Steele K (ed) Animal waste and the land water interface. Lewis Publ.CRC, New York, pp 239-251

Clapham WM, Zibilske LM (1992) Wood ash as a liming amendment. Commun Soil Sci Plant Anal 23:1209-1227

Codling EE, Chaney RL, Scherwell J (2002) Poultry litter ash as a potential phosphorus source for agricultural crops. J Environ Qual 31:954-961

Dakora FD, Phillips AD (2002) Root exudates as mediators of mineral acquisition in low-nutrient environments. Plant Soil 245:35-47

Demeyer A, Nkana JCV, Verloo MG (2001) Characteristics of wood ash and influence on soil properties and nutrient uptake: an overview. Bioresour Technol 77:287-295

Egle K, Römer W, Keller H (2003) Exudation of low molecular weight organic acids by Lupinus albus L., Lupinus angustifolius L. and Lupinus luteus L. as affected by phosphorus supply. Agronomie 23:511-518

Eichler-Löbermann B, Schnug E (2006) Crop plants and the availability of phosphorus in soil. In: Lal R (ed) Encyclopedia of soil science. Marcel Dekker, New York, pp 348-350

Eichler-Löbermann B, Köhne S, Kowalski B et al (2007) Effect of catch cropping on phosphorus bioavailability in comparison to organic and inorganic fertilization. J Plant Nutr 31:659-676

Eichler-Löbermann B, Schiemenz K, Makadi M et al (2008) Nutrient cycling by using residues of bioenergy production-II Effects of biomass ashes on plant and soil parameters. Cereal Res Commun 36:1259-1262

Erich MS, Ohno T (1992) Phosphorus availability to corn from wood ash amended soils. Water Air Soil Pollut 64:475485
Etiégni L, Campbell AG (1991) Physical and chemical characteristics of wood ash. Bioresour Technol 37:173-178

Franz M (2008) Phosphate fertilizer from sewage sludge ash (SSA). Waste Manag 28:1809-1818

Gilbert GA, Knight JD, Vance CP et al (1999) Acid phosphatase activity in phosphorus-deficient white lupin roots. Plant Cell Environ 22:801-810

Haarr A (2005) The reuse of phosphorus. Eureau position paper EU2-04-SL09, 2005

Hytönen J (2003) Effects of wood, peat and coal ash fertilization on Scots Pine foliar nutrient concentrations and growth on afforested former agricultural peat soils. Silva Fennica 37(2):219-234

Ikpe FN, Powell JM (2002) Nutrient cycling practices and changes in soil properties in the crop-livestock farming systems of western Niger Republic of West Africa. Nutr Cycl Agroecosyst 62:37-45

Jakobsen P, Willett IR (1986) Comparisons of the fertilizing and liming properties of lime-treated sewage sludge with its incinerated ash. Fert Res 9:187-197

Jamil M, Qasim M, Umar M et al (2004) Impact of organic wastes (bagasse ash) on the yield of wheat (Triticum aestivum L.) in a calcareous soil. Int $\mathrm{J}$ Agric Biol 6(3):468-470

Kania A (2005) Regulation of phosphate deficiency-induced carboxylate exudation in cluster roots of white lupin (Lupinus albus L.). Dissertation, University of Hohenheim

Krejsl JA, Scanlon TM (1996) Evaluation of beneficial use of wood-fired boiler ash on oat and bean growth. J Environ Qual 25:950-954

Lookman R, Vandeweert N, Merckx R et al (1995) Geostatistical assessment of the regional distribution of phosphate sorption capacity parameters $\left(\mathrm{Fe}_{\mathrm{ox}}\right.$ and $\left.\mathrm{Al}_{\mathrm{ox}}\right)$ in northern Belgium. Geoderma 66:285-296

Mandre M (2006) Influence of wood ash on soil chemical composition and biochemical parameters of young Scots pine. Proc Estonian Acad Sci Biol Ecol 55(2):91-107

Mozaffari M, Russelle MP, Rosen CJ et al (2002) Nutrient supply and neutralizing value of alfalfa stem gasification ash. Soil Sci Soc Am J 66:171-178

Mullins GL, Sikora FJ (1995) Effect of soil $\mathrm{pH}$ on the requirement for water-soluble phosphorus in triple superphosphate fertilizers. Fert Res 40:207-214

Muse JK, Mitchell CC (1995) Paper mill boiler ash and lime by-products as soil liming materials. Agron J 87:432-438

Neumann G (2007) Root exudates and nutrient cycling. In: Marschner P, Rengel Z (eds) Nutrient cycling in terrestrical ecosystems. Springer, Berlin

Nkana JCV, Demeyer A, Verloo MG (1998) Availability of nutrients in wood ash amended tropical acid soils. Environ Technol 19(12):1213-1221

Nkana JCV, Demeyer A, Verloo MG (2002) Effect of wood ash application on soil solution chemistry of tropical acid soils incubation study. Biores Tech 85:323-325

Nurruzzaman M, Lamers H, Bolland MDA (2006) Distribution of carboxylates and acid phosphatase and depletion of different phosphorus fractions in the rhizosphere of a cereal and three grain legumes. Plant Soil 281:109-120

Odlare M (2005) Organic residues-a resource for arable soils. Dissertation, Department of Microbiology, SLU. Acta Universitatis agriculturae Sueciae vol 2005, 71 
Ohno T, Erich MS (1990) Effect of wood ash application on soil $\mathrm{pH}$ and soil test nutrient levels. Agric Ecosyst Environ 32:223-239

Onwuka MI, Osodeke VE, Okolo NA (2007) Amelioration of soil acidity using cocoa husk ash for maize production in Umudike area of south east Nigeria. Trop subtrop agroecosyst 7:41-45

Page AL, Miller RH, Keeney DR (1982) Methods of soil analysis. Agron No 9, Part 2: chemical and microbiological properties, 2nd ed, Am Soc Agron, Madison, WI, USA

Patterson SJ, Acharya SN, Thomas JE et al (2004) Integrated soil and crop management: Barley biomass and grain yield and canola seed yield response to land application of wood ash. Agron J 96(4):971-977

Pearse SJ, Veneklaas EJ, Cawthray G et al (2007) Carboxylate composition of root exudates does not relate consistently to a crop species' ability to use phosphorus from aluminium, iron or calcium phosphate sources. New Phytol 173:181-190

Pels JR, De Nie DS, Kiel JHA (2005) Utilization of ashes from biomass combustion and gasification. 14th European Biomass Conference \& Exhibition, Paris, France, 17-21 October 2005, ECN-RX-05-182

Perucci P, Monaci E, Casucci C et al (2006) Effect of recycling wood ash on microbiological and biochemical properties of soil. Agron Sustain Dev 26:157-165

Phongpan S, Mosier AR (2003) Impact of organic residue management in nitrogen use efficiency in an annual rice cropping sequence of lowland Central Thailand. Nutr Cycl Agroecosyst 66:233-240

Pitman RM (2006) Wood ash use in forestry-a review of the environmental impacts. Forestry 79(5):563-588

Rosen CJ, Bierman PM, Olsen D (1994) Swiss chard and alfalfa responses to soil amended with municipal solid waste incinerator ash: growth and elemental composition. J Agric Food Chem 42:1361-1368

Saarsalmi A, Mälkönen E, Piirainen S (2001) Effects of wood ash fertilization on forest soil chemical properties. Silva Fennica 35(3):355-368

Sander M-L, Andrén O (1997) Ash from cereal and rape straw used for heat production: liming effect and contents of plant nutrients and heavy metals. Water Air Soil Pollut 93:93-108

Schilling G, Gransee A, Deubel A et al (1998) Phosphorus availability, root exudates, and microbial activity in the rhizosphere. Z Pflanzenernähr Bodenk 161:465-478

Schoumans OF (2000) Determination of the degree of phosphate saturation in non-calcarous soils. In: Pierzynski GM (ed) Methods for phosphorus analysis for soils, sediments, residuals, and water. Southern Cooperative Series Bulletin 396, North Carolina, pp 31-34

Schwertmann U (1964) Differenzierung der Eisenoxide des Bodens durch Extraktion mit Ammoniumoxalatlösung. Z Pflanzenernähr Bodenk 105:194-202

Shen J, Rengel Z, Tang C et al (2003) Role of phosphorus nutrition in development of cluster roots and release of carboxylates in soil-grown Lupinus albus. Plant Soil 248:199-206

Staunton S, Leprince F (1996) Effect of pH and some organic anions on the solubility of soil phosphate: implications for P bioavailability. Eur J Soil Sci 47(2):231-239

Suzuki A, Kashima H, Shinmachi F (2009) Analysis of dissolving functions of insoluble phosphate by phosphorus deficiency sensitive plants. The proceedings of the international plant nutrition colloquium XVI, Paper 1178, University of California, Davis

Uckert GB (2004) Versuche zur landbaulichen Verwertung von Holzaschen unter besonderer Berücksichtigung der Knickholzpotenziale Schleswig-Holsteins. Dissertation, University of Kiel

Van der Paauw F (1971) An effective water extraction method for the determination of plant-available soil phosphorus. Plant Soil 34:467-481

Van Reuler H, Janssen BH (1996) Comparison of the fertilizing effect of ash from burnt secondary vegatation and of mineral fertilizers on upland rice in south-west Côte d'Ivoire. Fert Res 45:1-11

Vance ED, Mitchell CC (2000) Beneficial use of wood ash as an agricultural soil amendment: case studies from the United States forest products industry. In: Power JF, Dick WA (eds) Land application of agricultural, industrial and municipal by-products. SSSA, Madison, pp 567-582

Yusiharni BE (2001) An evaluation of chicken litter ash, wood ash and slag for use as lime and phosphate soil amendments. Master Thesis. University of Mataram, Indonesia

Zhang F-S, Yamasaki S, Nanzyo M (2002) Waste ashes for use in agricultural production I. Liming effect, contents of plant nutrients and chemical characteristics of some metals. Sci Total Environ 284:215-225

Zhu Y-G, He Y-Q, Smith SE et al (2002) Buckwheat (Fagopyrum esculentum Moench) has high capacity to take up phosphorus (P) from calcium $(\mathrm{Ca})$-bound source. Plant Soil 239:1-8

Zimmermann S, Frey B (2002) Soil respiration and microbial properties in an acid forest soil: effects of wood ash. Soil Biol Biochem 34:1727-1737 